\title{
ISTANBUL'S TAKSIM SQUARE AND GEZI PARK: THE PLACE OF PROTEST AND THE IDEOLOGY OF PLACE
}

\author{
Murat Güll ${ }^{a}$ John Dee ${ }^{b}$, Cahide Nur Cünük ${ }^{c}$ \\ a Department of Architecture, TOBB University of Economics and Technology, \\ Söğütözü Caddesi No. 43, Ankara, Turkey \\ ${ }^{\mathrm{b}}$ Architecture Program, International University of Sarajevo, \\ Hrasnička cesta 15, Sarajevo, Bosnia and Herzegovina \\ 'Department of Architecture, Fatih Sultan Mehmet Vakıf University, \\ Merkez Efendi Mah. Mevlevihane Cad., Yenikapı Mevlevihanesi No: 25, Zeytinburnu, Istanbul, Turkey \\ E-mails: ${ }^{2}$ mgul@etu.edu.tr(correspondingauthor); bjdee@ius.edu.ba; ${ }^{\mathrm{c}}$ cahidenurcunuk@gmail.com
}

Received 17 December 2013; accepted 05 March 2014

\begin{abstract}
May 2013 saw Istanbul witness a massive public demonstration. The incident began on 28 May when a small group of environmental activists tried to save Gezi Park, one of the most iconic green spaces in the Taksim district of central Istanbul. The park dates back to the 1940s and is well-known as public promenade. The modest demonstration was triggered by a government decision to reconstruct a former Ottoman Artillery Barracks. Within a few days, it developed into a violent uprising on an unprecedented scale lasting almost an entire month. Crowds not only gathered in Istanbul but also in many other Turkish cities such as the capital, Ankara. International media broadcast the protests live from Taksim Square turning the Gezi Park protest into an international phenomenon. Today the Park has become a reference point in Turkish politics where almost every issue is linked to the 'spirit of Gezi'. It made a modest protest over an inner city promenade into a vivid symbol of political opposition. This paper will analyse historically the Taksim Square project and the ideological conflicts it evoked in Turkish society.
\end{abstract}

Keywords: modernism, ideology, protest movement, public space, urban landscape.

Reference to this paper should be made as follows: Gül, M.; Dee, J.; Cünük, C. N. 2014. Istanbul's Taksim Square and Gezi Park: the place of protest and the ideology of place, Journal of Architecture and Urbanism 38(1): 63-72.

\section{Introduction}

Cities throughout history have functioned as vivid symbols of the civilisations to which they belong. Such cities embody strong symbolic meaning with respect to urban space as exemplified in the grand Baroque designs of $17^{\text {th }}$ and $18^{\text {th }}$ Century Italy and France. Wim Blockmans describes cities as 'theatres' where political regimes show their ideology and social practices (Blockmans 2003). Likewise Spiro Kostof argues that 'In every age urban spaces - streets and squares - have served to stage spectacles in which the citizenry participated as players and audience' and that 'the dramatization of urban form was a function of autocracy' from the political point of view (Kostof 1999). Capital cities have been used as platforms for state rituals, festivals, celebrations and other public events where space and building alike can embody symbolic meaning with reference to political power, the nobility and the wider public. Many spaces have forged unique meanings and destinies through landmark events such the execution of Louis XVI at the Place de la Concorde, Paris 1793, the Tiananmen Square protests of 1989 in Beijing and the civil rights speeches by Martin Luther King and others in Washington DC, 1963. Hence people embrace and attach symbolic importance and meaning to places because of their associations with specific events in human history. Other well-known historical 
places where people gather for celebration and protest are Alexanderplatz in Berlin, Times Square, New York and Tahrir Square, Cairo. Istanbul's Taksim Square is such a place with a powerful historic association and meaning in respect of political power, celebration and public demonstration.

The Taksim district lies on the European side of the Istanbul metropolis. Designed in the 1940s, Taksim Square and Gezi Park were to become the most important public spaces in contemporary Istanbul. The early decades of the Turkish Republic brought Taksim to prominence as the republican ideological showcase of modernisation. Hence its modern recreational facilities and modernist buildings were critical in the history of this process. The Square became associated with many public events such as political rallies, labour demonstrations, New Year jamborees and national football celebrations. Today it is a powerful symbol for many social and ideologically based causes: a place where protest groups traditionally air their grievances. It has inscribed an indelible imprint on city's morphology as a place used by governments to deliver their ideologies and policies to the people. It is also a place where politicians have acted as pseudo urban designers to the extent that today its design quality is little more than a lifeless void. But as recent events have shown, the Square still retains a powerful symbolic status as arguable the most important public gathering place in Istanbul.

The paper will first appraise the historical development of Taksim Square and its role in Turkish politics from the Late Ottoman period when Taksim played a pivotal role in attempts to resuscitate an aged empire. Next it will analyse the contemporary events and battles waged over fundamental ideological value sets that catapulted Taksim to national and international prominence. Of particular interest here is the way a modest protest over a pedestrianisation proposal developed into a major national political crisis. Finally insights will be offered on the historic significance and symbolism of Taksim Square and Gezi Park.

\section{Taksim in late Ottoman times}

Taksim's urban history began in 1732 under the reign of Sultan Mahmud I with the construction of a water distribution building. Located on the northern slopes of the Golden Horn, Taksim district lies across the water from the ancient walled city of Istanbul. Ottoman Istanbul had four principal districts: The old City of Istanbul (Istanbul proper), Galata across the Golden Horn, Eyüp on the northern shores of the Golden Horn and Üsküdar on the Asiatic shores of the Bosphorus. Galata had been home to Genoese merchants since Byzantine times. The district on the hill above Galata was named Pera by the Greeks, meaning 'across the Golden Horn', and Beyoğlu by the Turks. Beyoğlu gradually became a centre for Westerners who resided in Ottoman Istanbul. It housed diplomatic envoys and missions and displayed western style cafes, hotels restaurants and entertainment venues - all of which enriched the district over time making it the most Europeanised part of Istanbul in the 19th Century (Gül 2012).

Water was supplied to Pera by canals constructed in the 18th Century, and Taksim, being the most prominent point of Beyoğlu, became a water distribution centre for the three major dams that supplied the city. The dams were constructed in the reign of Mahmud I to supply Galata and the northern shores of the Bosporus (Kuban 2000; Cezar 2002). A building constructed in 1732 ' $\mathrm{mak}-$ sem' (meaning 'place of distribution') is the origin of the name of the Taksim district. In the late 18th century Beyoğlu expanded as far as the maksem with the boundary marked by the road connecting Pera to Taksim - the Grande Rue de Pera or today's İstiklal Street.

The modernisation policies of the Ottoman Empire made Taksim one of the most sought after destinations in Istanbul. The Artillery Barracks, constructed in 1806 and renovated in the mid-19th Century during the reign of Abdülmecid, marked Taksim's importance in the urban morphology of Istanbul. Mecidiye and Gümüşsuyu Barracks and Gümüşsuyu Military Hospital were the other large-scale buildings constructed in the Taksim district during the late Ottoman period. Many other noteworthy buildings were constructed in Taksim during the first two decades of the $20^{\text {th }}$ Century to take advantage of the transport connections made possible by the electric tram network completed in 1914.

\section{Taksim Square and the Kemalist ideology}

The end of the First World War saw the Ottoman Empire collapse and the birth of a new secular Turkish Republic in 1923. Under the leadership of Mustafa Kemal Atatürk, the new Turkish Republic represented a significant turning point in Turkish history. It marked the beginning of an intense modernisation process that brought with it fundamental institutional change to the country's political and social structure. Although the roots of Turkish modernisation can be traced back to early 18th Century Ottoman administrations, the new Republican reform programme was radically different. One of its principal aims was a wide-ranging transformation based on Western secular values of traditional Ottoman society. The reforms included the removal of political figures, the dismantling of institutions and symbols of the Ottoman Empire and their replacement 
with a set of secular principles for the foundation of a new nation state. Therefore all recognisable symbols of the ancient régime, ranging from dress codes to the alphabet were outlawed, removed or changed to conform to the perceived western standards of the time.

The Kemalist elites, as with many other revolutionary regimes, saw architecture and urban planning and design as the key visual indicators of cultural modernisation (Bozdoğan 2001; Gül 2012). All resources and expertise were subsequently directed to the creation of the new capital, Ankara. During this period Istanbul was effectively forgotten losing its privileged status and much of its multi-ethnic character. These 'silent' years saw only one noteworthy development in Taksim: the construction of a monument to the Republican cause designed by the Italian sculptor Pietro Canonica and landscaped by architect Giulio Mongeri. While the monument made Taksim Square one of the most important public places in modern Turkey (Fig. 1), Kemalist recognition of Istanbul had to wait for many years. This finally came with the appointment of Henri Prost, a French urban designer, as the Chief Planner for Istanbul in the mid1930s. Prost prepared a master plan for the city in 1939 and stayed in his position until 1950 (Gül 2012).

During his term in office, Prost's plan was executed piece meal because of severe economic problems in and after the Second World War. These same difficulties were exacerbated by the high costs and unrealistic expectations of the proposals. Not surprisingly the plans attracted strong criticism from different political and professional circles who saw them as more concerned with cosmetic matters rather than the real issues of Istanbul (Gül 2012). The plans, nevertheless, continue to guide the planning of Istanbul to this day with the reorganisation of Taksim Square and its environs being among the few completed works during Prost's term as city planner. Taksim and its surrounding districts then presented the ideal place for Prost to implement the planning principles of the Kemalist regime.

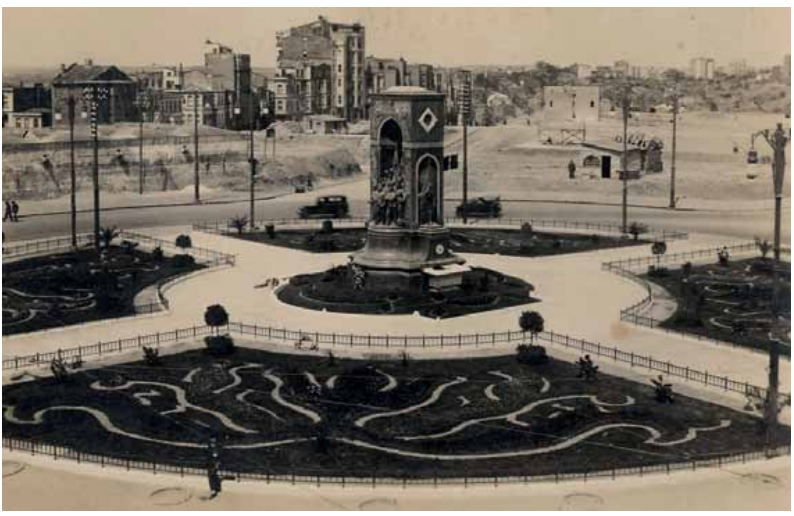

Fig. 1. Republican Monument in Taksim Square c. 1928 (MSGSÜ Restoration Department Archives)
The first major project in Taksim by Prost was the demolition of the Artillery Barracks to create a public promenade (Fig. 2). In the 1930s the derelict Barracks and its huge courtyard were used as a football field, which eventually made way for the construction of a modern park and promenade named after İsmet İnönü who became the president of Turkey on Atatürk's death in 1938 (Figs 3, 4). İnönü Gezisi (İnönü Promenade)

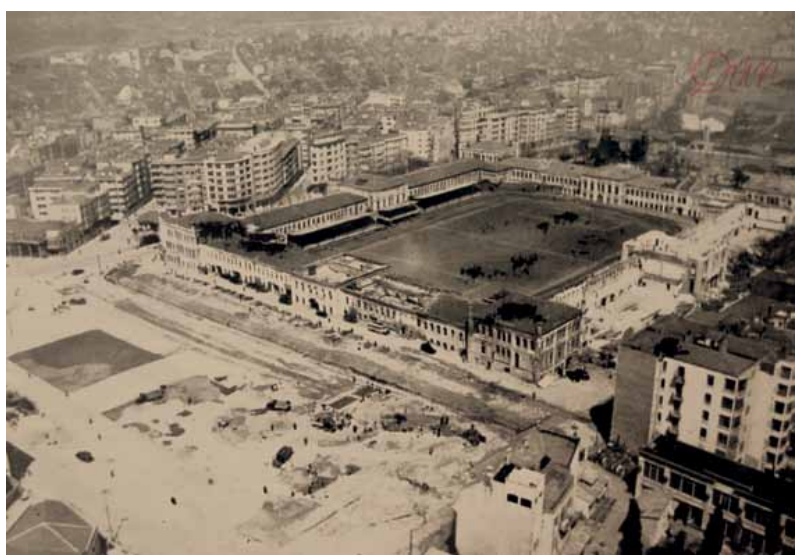

Fig. 2. Artillery Barracks in Taksim c. 1930s. (Reproduced from Güzelleşen Istanbul, Istanbul Municipality, 1943)

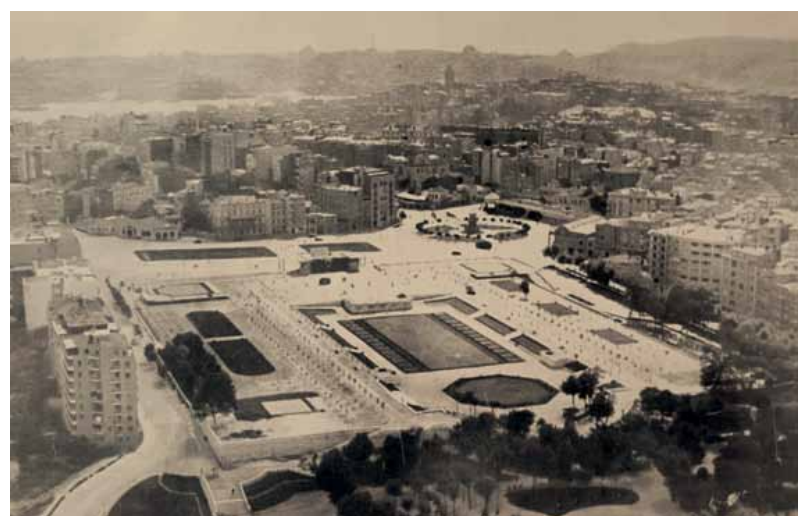

Fig. 3. Taksim Square and the İnönü Promenade (Gezi Park) c. 1940s. (Reproduced from Güzelleşen Istanbul, Istanbul Municipality, 1943)

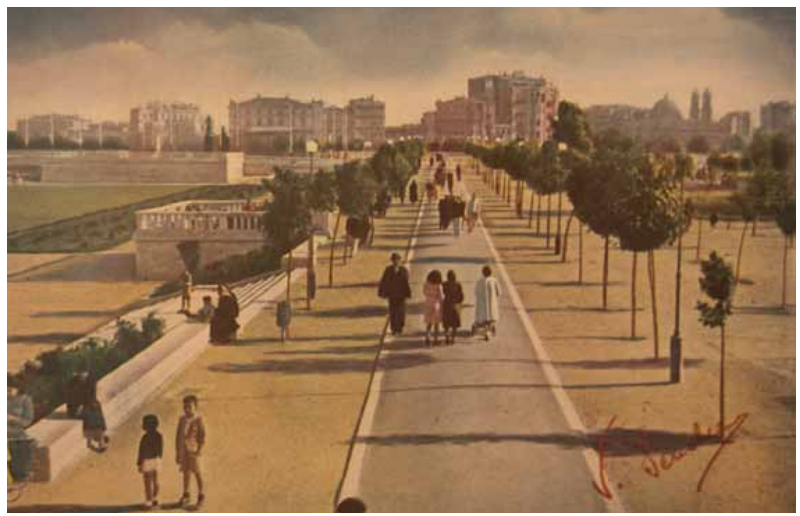

Fig. 4. An artist's illustration of the İnönü Promenade (Gezi Park) in a municipality's propaganda book c.1940s. (Reproduced from Güzelleşen İstanbul, Istanbul Municipality, 1943) 
occupied an area of 62,000 sqm and represented a truly modern western style park with tree-lined walking routes, grassed areas, seating benches and kiosks for recitals of the Municipality's Philharmonic Orchestra (Gül 2012). İnönü Promenade was accompanied by a new park (Maçka Park) in the northeast and a football stadium (1946) and an open air theatre (1947). The State Radio Hall (1945), Sports and Exhibition Palace (1949) and modern apartment buildings along the tree-lined Cumhuriyet Avenue connected Taksim Square to the district of Nișantaşı in the north. These new works brought the modern precinct to life where the seeds of a secular society were sown. Taksim, therefore, became the most important urban space in Istanbul for official celebrations and the display of Republican urban planning principles in much the same way that Times Square, New York is used as a participatory public sphere (Makagon 2003).

\section{Taksim Square after World War II}

Post World War II saw Turkey embrace a western style multi-party democratic system. The importance of Taksim and its surrounds continued in the 1950s and 1960s with the construction of important buildings to reflect the new political and social order. Significant among these was the 1956 Istanbul Hilton Hotel at the northern end of the İnönü Promenade. Designed by the American architectural firm Skidmore, Owings and Merrill and the celebrated Turkish architect Sedad Hakkı Eldem it was an early and outstanding example of post-war International Style architecture in Turkey. Beyond its stylistic character, the Istanbul Hilton symbolised the increasing American influence in Turkish politics after the Second World War. Another prominent project for Taksim was the construction of an opera house. Although initial thoughts about a performance space had its origins in the early 1940s, the construction began in 1946. The project was later transformed into a multi-purpose cultural centre and completed in 1969. A year later the building was badly damaged by fire and following repairs and renovation it reopened in 1978 and named Atatürk Cultural Centre (AKM). This rectangular prismatic building, with many typical features of the above mentioned International Style, became an icon of secular architecture in Istanbul. Taksim district also saw the construction of several high-rise buildings including the Military Officers' Club (1968), the present day Ceylan Intercontinental Hotel (1973) and the Marmara Hotel (1977), which together represent the different shades of modern architecture in Istanbul.
Taksim Square was subject to several renovation initiatives in the late 20th Century. Noteworthy among these was the urban design completion of 1987. The design brief focused on the reorganisation of various squares in Istanbul including Taksim and coincided with important junctures in Turkish political history during the turbulent years of the second half the 1970s, which culminated in the military coup of 1980 . This resulted in the dissolution of all political parties and the drafting of a new constitution by the military junta. The elections of 1983 brought a new party to power and an open market economy bringing with it significant infrastructure projects in transport and telecommunications. Political and economic stability from 1984 to 1989 brought large-scale urban interventions by Istanbul's ambitious mayor, Bedrettin Dalan. These and other intended works such as the reorganisation of major urban spaces had a significant impact on the city's morphology. And as set out in the urban design competition booklet, Taksim once more became a showcase of modern Istanbul and a symbol of the 'Republican era' of Turkey (Taksim Meydanı ... 1987).

First prize in the design competition was awarded to Vedat \& Hakan Dalokay's project. It proposed a huge pool in Gezi Park and underground tunnels to connect the Promenade, Taksim Square, AKM and İstiklal Street. The tunnels, in a similar way to the cur-

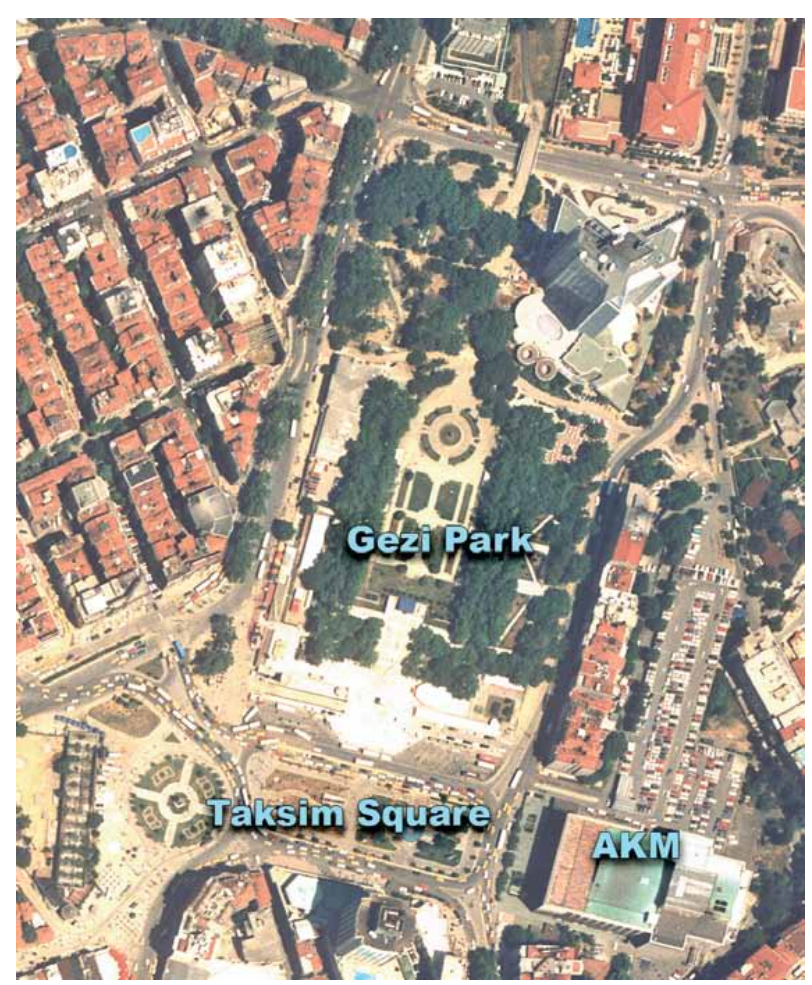

Fig. 5. Aerial photo of Taksim Square and Gezi Park before the pedestrianisation project, c. 2002. Istanbul Municipality 
rent proposal, were for vehicular traffic movement and to allow the expansion of the pedestrian area between İstiklal Street and Taksim Promenade. The winning project, however, never left the drawing board in effect allowing Taksim Square to continue as a bus interchange. Another important project was the opening of Tarlabaşı Boulevard. Originally planned in the late Ottoman period and later proposed by Prost, it was finally completed in 1988 and included a wide avenue connecting the Historic Peninsula to Taksim. The problem, however, was that it also added to the traffic load in the square (Fig. 5).

\section{Taksim's pedestrianisation project}

Another new chapter opened in Turkish political history in the early years of the 21st Century. The general elections of 2002 brought to power the social-conservative Justice and Development Party (AK Party) led by Prime Minister Recep Tayyip Erdoğan, the former mayor of Istanbul from 1994 to 1998 . The flux of international politics, Turkey's geographic position in the Middle East and the Balkans together with spectacular economic success saw the AK Party embark on major structural changes to the Turkish political systems. With 50\% popular support, a figure not been seen in Turkish politics since 1965, the AK Party government made noteworthy improvements in the economy, education, health, transport and many other sectors. Its success in public administration and economic management enabled the government to consolidate its powerbase and reshape relationships between the Kemalist state apparatus and Turkish political institutions. The most important change here concerned the triumvirate relationship among the pro-Kemalist army, Kemalist bureaucracy and government, which since the mid-20th Century, had predominantly been presided over by centre right and conservative parties. And unlike the previous military interventions in 1960, 1971, 1980 and 1997, the AK Party government was able to unravel and stop various plots to usurp political power by the military and their supporters in the bureaucracy. This in effect brought an end to the political hegemony of Kemalist ideology - representing a radical shift in power relations that impacted on Istanbul's urban expansion, in particular Taksim.

Vico's aphorism that 'history repeats itself' has some validity here. As with past Ottoman and Republican governments, the AK Party government used Istanbul as the showpiece for its ideology and policies. Hence the city was pushed onto the political agenda during the 2011 general elections when the government announced a group of large scale proposals, the so called

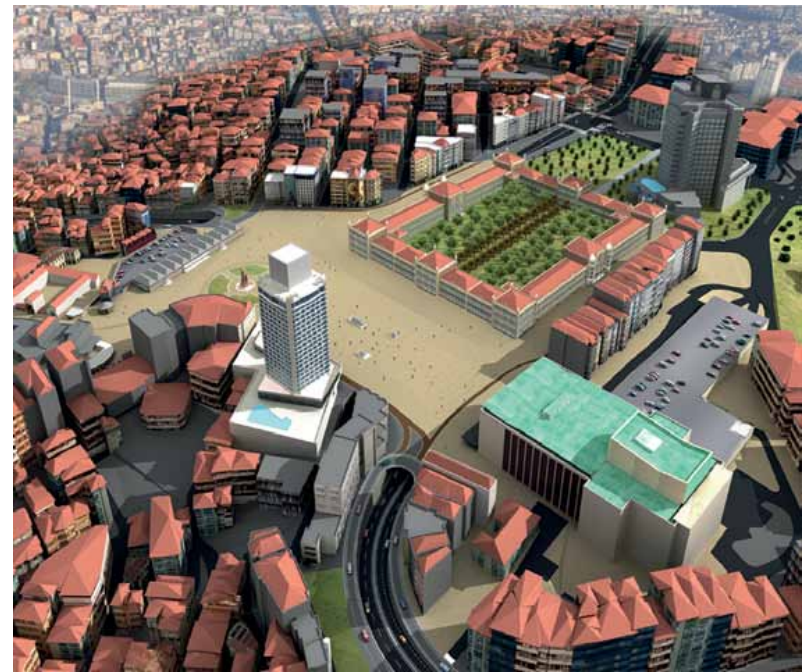

Fig. 6. An illustration of the Taksim pedestrianisation project. Istanbul Municipality

'Crazy Projects', which included initiatives to construct a third bridge over the Bosphorus, a new waterway to connect the Black Sea to the Sea of Marmara and the construction of a new airport to be one of the world's biggest. Also noteworthy here was the government's announcement to reorganise Taksim Square by creating a gigantic pedestrian area and placing all roads to Taksim under the Square.

The reconstruction of the former Artillery Barracks demolished in the early 1940s to create İnönü Promenade known as Gezi Park, was a major part of the project and required the removal of many mature trees and green areas. The above-mentioned underground road proposal was approved unanimously by the Municipal Assembly in September 2011 (Fig. 6). And the Council of Preservation of Cultural and Natural Heritage approved the pedestrianisation project in 2012 subject to the cancellation of some of the proposed underground roads and the works commenced in October of the same year. The government also wanted to demolish the AKM and construct a new opera house in the 'baroque' style, which recalled the relevance of Roman Jakobson's semiotic mode in relation to understanding aesthetic representation (Allingham 2008).

\section{Underlying ideological issues}

Although widespread consensus suggested that something needed be done in Taksim, the project attracted severe criticism by architects, professional bodies, nongovernmental organisations and community groups. Strong objections were made in relation to the municipality's management of the proposed redevelopment 
of Taksim Square, particularly the lack of consultation with relevant professional organisations and the wider community. The government's arrogance, and especially the Prime Minister's personal involvement, was also subjected to vehement criticism in architectural circles. Esra Akcan, for example, made the point that 'architectural representation' is an important vehicle to leave 'a permanent stamp' on a country, and the current government's attempts to replace the republican created Gezi Park and AKM with neo-Ottoman buildings is a vivid example of this 'syndrome' (Akcan 2013). Korhan Gümüş, the president of Human Settlements Association and a member of Taksim Solidarity Group, described the project as an example of 'authoritarian urban management' (Kılınçarslan 2012). Other objections addressed technical aspects of the proposed works such as the proposed tunnels would cause traffic congestion and not improve pedestrian access (Kılınçarslan 2012; Gürsel 2012). The strongest objections, however, were directed at the proposed reconstruction of the Artillery Barracks on the grounds that it would remove Gezi Promenade and also harm trees in the area. And as noted by Nur Akın (2012) it was also debatable whether the proposed reconstruction would be appropriate in terms of contemporary heritage practice and philosophy. The above objections also led to public statements by leading figures such as politicians, artists and activists. The reconstruction of the Barracks as a shopping mall attracted further objections on the grounds that it would change in the atmosphere and ambiance of the park from a public recreation area to a commercial precinct. Gülşen Özaydın, a professor in urban design with specialised knowledge on Istanbul's urban planning history, believed the proposal recalled the 19th Century concept of 'sventramenti' in that it would create significant environmental problems, alter the character of the space and not help the proposed pedestrianisation (Özaydın 2012).

The most profound criticism, however, focused on ideology. Kemalist loyalists saw Taksim as a purpose-built urban space representing the spirit of the republican cause. Its physical manifestation portrayed powerful symbolic meaning that underlined the radical shift from the values associated with Ottoman identity to a new, modern and secular republic. To the Kemalist reformers of the early Republican era, the Historic Peninsula and its unique character of narrow streets, cul-de-sacs, old timber dwellings, beautiful minarets and domed silhouette represented the 'outdated' side of the Ottoman Empire. Taksim, on the opposite side of the Golden Horn, with its large avenues, parks, pedestrian paths and modernist buildings was considered the vivid symbol of a youthful, progressive and modern Turkish republic. In sharp contrast to old Istanbul's social atmosphere of restrictive religious bound traditional norms and customs, Taksim became the place where men and women could mix and participate equally in a secular atmosphere of social and recreational activities. İnönü Promenade, for example, was a place where men and women freely enjoyed a mixed social life, one not possible in the traditional neighbourhoods of old Istanbul in the 1930s and 1940s. In the eyes of the Kemalist elite and intelligentsia, Taksim is seen a special public space free from the symbols of the restrictive Ottoman culture. The government's intention to reconstruct the barracks and demolish the AKM was considered by the same circles as a provocative action with the clear intention to erase the republican memory of the place and by doing so remove the Square's symbolic 'free' status. This position corresponds closely with McCann's (2003) observation that urban politics is frequently characterized by political strategies that frame reality.

Islamist and conservative groups, on the other hand, have always viewed Taksim's secular character as problematic. Many Islamists believe Taksim should be 'annexed' to the overall character of the historic city. For this reason conservative circles since 1950s have worked assiduously to have a mosque constructed in Taksim. The mosque is a strong Islamic symbol and its construction would be an ideological victory for the Turkish political Islamist movement. Various mosque proposals for Taksim have appeared in newspapers during almost all election campaigns since the 1960s. In essence, the conservatives see the mosque as the signature of Istanbul's Turkish-Islamic culture and as such it has been a recurring theme for Taksim in the speeches of Islamist politicians. Necmettin Erbakan, a former prime minister and key figure of political Islam in Turkey, said: 'People want the mosque. They [bureaucracy] have listed the site for the mosque as a conservation precinct. Then we will build it in the park [Gezi Park]. The outcome would be even better in this way' (Taksim'de camiyi ... 1995). The context of above issues was made clear by Douglas (2012) who noted that development operates within complex cultural contexts and that factors such as '...'cultural sensitivity' and 'cultural sincerity' both play a role'.

For Kemalists the issue has always been symbolic. Accordingly the mosque project is a deliberate attack on the achievements of Atatürk's reforms. Oktay Ekinci, former chair of the Turkish Chamber of Architects, believed the idea of constructing of a mosque together with shops to provide income for its maintenance as a smoke screen by some 'uncivilised circles' to construct 
a large commercial space in Taksim Square (Taksim'e cami ... 1994). Interestingly, Mills (2006) argues that such debates redraw and contest the boundaries of the nation in the space of the urban, a point supported by Ealham's (2005) reference to Henri Lefebvre in his recognition of the duality of the modern city: i.e. how for some it is a space of play and liberation, and for others a centre for power and repression. This same observation was made by Uysal (2012) in her analysis of the power dynamics of urban social movements in a different district of Istanbul.

The ideological struggles in the 1960s and especially the 1970s brought with them another layer of symbolism in that Taksim would also become synonymous with socialist ideology and the labour movement. Being the largest urban space in the city, Taksim since the 1950s has been constantly used for political rallies, public meetings and demonstrations. The Labour Day demonstration of May 11977 marked another major turning point in Turkish political history. A violent and bloody incident occurred at these demonstrations where 34 people were killed and hundreds injured by an unidentified gunman concealed in one of the surrounding buildings. This tragedy underlined Turkey's political instability in the 1970s where volatile conditions brought anarchy and street fighting among militant political groups. The above Labour Day demonstration is a pivotal event in the history of the square and established a strong physiological link between Taksim and leftist ideology in Turkey.

Since this time, the May 1 Labour Day has lead to tensions between government officials and labour organisations with respect to the organisation of remembrance celebrations where extreme actions such as stopping public transport and blocking road access have been taken to prevent people gathering in the Square.

Taksim's long and complex history and strong association with the republican movement, in the eyes of Turkey's intelligentsia, made the proposed redevelopment a direct attack on Republican secular values associated with the Square. Gümüş argues that the Prost project in the 1930s was not an ordinary planning activity, but more an implementation of the 'republican manifest' for Istanbul making Taksim a fertile place for controversy between republican ideology and conservative values (Ertaş 2011). Betül Tanbay, a professor of mathematics and an active member of the Taksim Platform, for example, links the date of approval for the reconstruction of the Barracks to a military intervention against the Islamic party government in 1997 that occurred on the very same day 15 years before. She further claims the decision was deliberately taken on that date for vengeance (Kongar, Küçükkaya 2013).
While the Taksim Square issues were being debated in academic circles and NGOs, the municipality began works to widen the pedestrian pathways along the northern boundary of the Gezi Park. On 27 May 2013 the retaining wall between the park and road was demolished and in the process a number of trees were uprooted. A small group of environmental activists stepped in front of the machines preventing further destruction and approximately 50 people set up tents in Gezi Park for the night. The following morning municipal workers set the tents on fire and the protesters were forced to leave the park. The incident was to ignite protest action on a large scale, first in Istanbul and then in other cities across Turkey. Police responded to the protests with large amounts of tear gas and pepper spray provoking even greater public anxiety - an action that recalls the Occupy Wall Street protests and the 'Arab Spring' revolutions where social media was used effectively to further the respective causes. Activists in Taksim learned from this tactic and published more than two million tweets on 1 June 2013 (Barbera, Metzger 2013), which supports Castells' (2007) observation that the '... media have become the social space where power is decided'. Following the above electronic media campaign, new groups formed and joined the protest ranging from extreme leftists to Kemalists and 'anti-capitalist Islamists' as well as some violent extremist organisations. Indeed Pinto's (2008) observation that, as political forces fight for 'supremacy', urban movements can became a 'coveted ally and potential source of legitimacy' has some credence here.

The protests evolved into violent opposition against government policy where different social groups used the Gezi Park protest to unleash their grievances into the mainstream political sphere. Sadly five protesters and one police officer lost their lives. In many cities across Turkey bank offices, shops, cars and public buses were looted and vandalised. In fact some protesters even attempted to loot and occupy the Prime Minister's working office in Istanbul. In this sense, Moncada's (2013) finding about the way actors and interests operating 'at multiple territorial and institutional scales' can 'influence the local dynamics and consequences of urban violence' is borne out by the above events.

When the Gezi Park protests and government response entered the international political arena, this created diplomatic crises among Turkey and allied countries and international organisations. The United States, for example, issued several statements about the Gezi Park incidents. One released by Laura Lucas, Spokesperson for the White House National Security Council, warned that nonviolent demonstrations were 'part of democratic expression, and we expect 


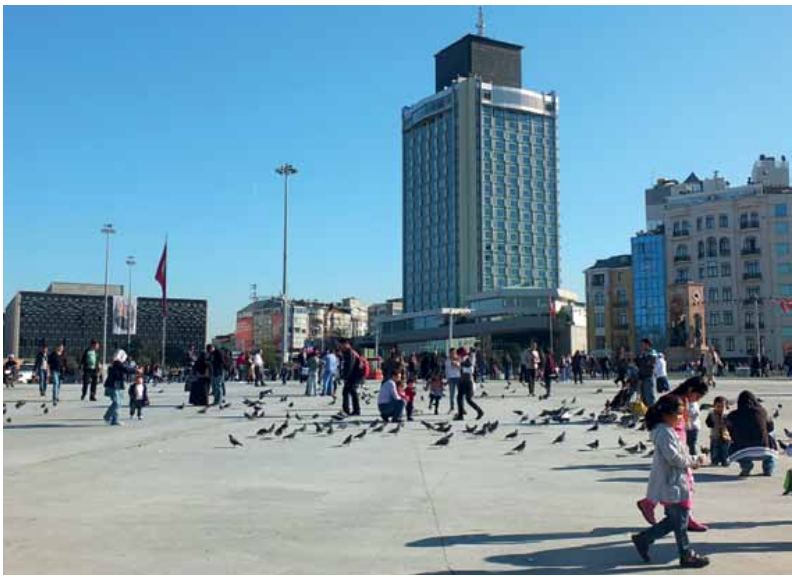

Fig. 7. Taksim Square after vehicular roads have been placed underground. C. N. Cünük

public authorities to act responsibly and with restraint' (Resneck 2013). The European Parliament too released a resolution urging Turkey to consult with the public over issues related to the city and urban development plans and condemned the 'disproportionate and excessive use of force' by police in the Gezi Park protests (European Parliament JMR, 13 June 2013).

The government's response to the protests was problematic from the outset. The use of excessive police force and tear gas provoked the masses and fuelled tensions between the government and environmental groups, which gave the Gezi Park protest considerable traction to move onto a larger political stage. Although government representatives later admitted their mistake and apologised for the use of excessive force, they read the events as part of a larger planned rising against the $\mathrm{AK}$ Party government by remnants of the old system who had lost their privileged status in Turkish politics. These were the Kemalist elites, large companies who benefited from the old system, and an internationally backed 'interest lobby' who wanted to force the government to keep interest rates artificially high for profit and manipulation of the stock market. Prime Minister Erdoğan's speech of 1 June acknowledged the 'protestors' right to express their opinion but at the same time stated that some extremist groups had manipulated the good will of the demonstrators'. He then blamed the extremists as being responsible for the vandalism (Sabah, 1 June 2013).

In this turbulent atmosphere, and following a court decision, the government held over its decision to reconstruct the old Artillery Barracks. Some renovation works were undertaken in the highly damaged park and square. Gezi Park was reopened for public use on 8 August 2013. The Pedestranisation project was completed with the construction of the underground roads to Taksim Square from the north and

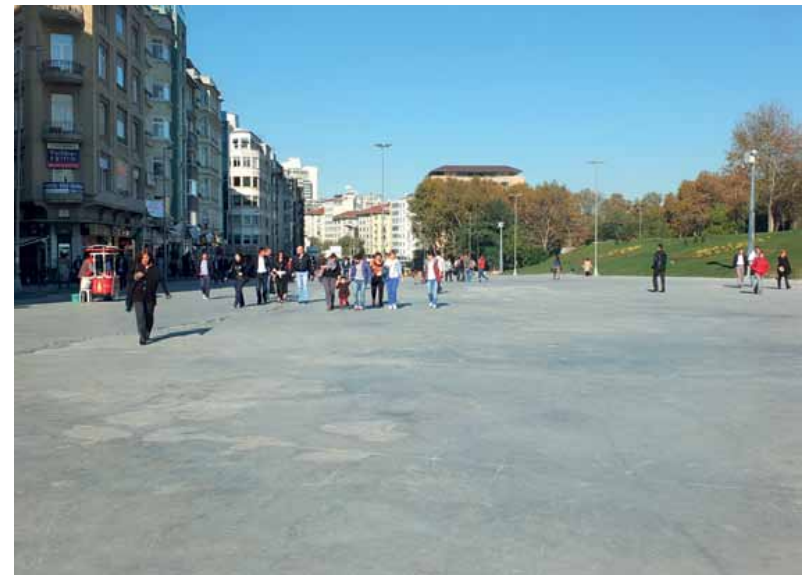

Fig. 8. Southern end of Cumhuriyet Avenue after vehicular roads have been placed underground and Gezi Park (right). C. N. Cünük

south. Although the landscaping works are yet to be completed, the large concrete plaza has now been opened for public use (Figs 7,8 ).

\section{Conclusion}

The Gezi Park protest at Taksim Square presents a rich study on the political symbolism of urban place. A modest environmental protest against the redevelopment a park and the loss of a few trees on face value would be considered trivial in mainstream national politics. The design proposal consisting of the reconstruction of the old artillery barracks, the demolition of the AKM and the construction of a 'baroque' opera house among other things, masked a set of deeper ideological and cultural issues that can be traced back to past Ottoman and Kemalist administrations. Taksim had been actively promoted as Istanbul's cosmopolitan district as far back as the late Ottoman period when a gradual process of Europeanisation was underway. It was the Kemalists, however, who took Taksim to new heights by turning it into a political showcase to promote modernisation policies. This included the redesign of Taksim Square along secular lines with public displays of new western style dress codes and equality of women to enjoy outdoor activities in a public space.

The incumbent Erdoğan Government with its Islamic traditionalist support base decided, as other administrations had done before, to use urban design as a symbol to promote an ideologically based policy agenda. Hence Taksim again became a showcase to signal a new political agenda aimed at curbing the power and influence of Kemalist political elites. Prime Minister Erdoğan, in a similar way to his politically powerful predecessors, personally involved himself in the project. 
As a political strategy, however, the project ran into unexpected obstacles. These were that it failed to fully understand the deep-seated underlying cultural values and associations with respect to the history of the Square. The ill-advised tactics of the municipality in destroying the tent protest together with the heavy-handed police response provided the material conditions for a modest protest to galvanise different political interest groups and individuals into mass protest against the government. Many groups and individuals who joined the protest had no real interest in the design issues and simply used Taksim and Gezi Park as a vehicle to air their grievances. This was especially so in the Kemalist circles where the focus of concern was the erosion of secular practices and policies of the Republican modernisation agenda. In the end, the government was forced to back-down and Gezi Park was saved for the time being. The current situation, however, is fragile as Taksim will remain a strong symbol of ideological contest during and after the municipal elections scheduled for March 2014.

Finally, the Taksim protest is a telling reminder of the power of place in cities. It underlines the myriad of values, symbols, ideologies, associations and meanings such places hold and the passions they can ignite in the minds of people.

\section{References}

Akcan, E. 2013. Fiziksel ve sanal kamusal mekanın keşfi, XXI(121): 31

Akın, N. 2012. Yeni Tarihi Yapı?: Taksim Topçu Kışlası, Mimarlik Dergisi 364: 27-28.

Allingham, P. 2008. Urban space, representation, and artifice, Knowledge, Technology \& Policy 21(4): 163-174. http://dx.doi.org/10.1007/s12130-008-9061-9

Barbera, P.; Metzger, M. A. Breakout role for Twitter in the Taksim Square protests?, Aljazeera, 1 June, 2013 [online], [cited 08 October 2013]. Available from Internet: http://www.aljazeera.com/indepth/opinion/ 2013/06/201361212350593971.html

Başbakan'dan Gezi Parkı açıklaması, Sabah, 1 June, 2013 [online], [cited 08.10.2013]. Available from Internet: http://www. sabah.com.tr/Gundem/2013/06/01/basbakan-erdogankonusuyor

Blockmans, W. P. 2003. Reshaping cities: the staging of political transformation, Urban History 30(1): 7-20. http://dx.doi.org/10.1177/0096144203258175

Bozdoğan, S. 2001. Modernism and nation building: Turkish architectural culture in the early republic. Seattle: University of Washington Press.

Castells, M. 2007. Communication, power and counterpower in the network society, International Journal of Communication 1: 238-266.

Cezar, M. 2002. Osmanlı Başkenti İstanbul. Istanbul: EKAKESS Vakfi.
Douglas, G. C. C. 2012. Cultural expectations and urban development: the role of "cultural sensitivity" and "cultural sincerity" in local growth politics, Sociological Perspectives 55(1): 213-236. tp://dx.doi.org/10.1525/sop.2012.55.1.213

Ealham, C. 2005. An imagined geography: ideology, urban space, and protest in the creation of Barcelona's "Chinatown", c.1835-1936, International Review of Social History 50: 373-397. http://dx.doi.org/10.1017/S0020859005002154

Ertaş, H. 2011. Taksim düğümü nasıl çözülür?, XXI(103): 32-38.

European Parliament Resolution, 13 June 2013. [Online], [cited 10 October 2013]. Available from Internet: http://www.europarl. europa.eu/oeil/popups/summary.do?id=1277156\&t=d\&l=en

Gül, M. 2012. The emergence of modern Istanbul: transformation and modernisation of a city. London: IB Tauris.

Gürsel, E. 2012. İstanbul kenti en önemli meydanını kaybedebilir!, Mimarlkk Dergisi 364: 23-26.

Güzelleşen İstanbul. 1943. Istanbul: İstanbul Belediyesi.

Kılınçarslan, C. 2012. Taksim yayalaştırma projesi nedir?, Toplumsal Tarih Dergisi 218(2): 17-20.

Kongar, E.; Küçükkaya, A. 2013. Gezi direnişi. Istanbul: Cumhuriyet Kitapları.

Kostof, S. 1999. The city shaped: urban patterns and meanings through history. London: Thames \& Hudson.

Kuban, D. 2000. İstanbul bir kent tarihi: Bizantion, Konstantinopolis, İstanbul. Istanbul: Türkiye Ekonomik ve Toplumsal Tarih Vakfı.

Makagon, D. 2003. A search for social connection in America's town square: Times Square and urban public life, The Southern Communication Journal 69(1): 1-21. http://dx.doi.org/10.1080/10417940309373275

McCann, E. J. 2003. Framing space and time in the city: urban policy and the politics of spatial and temporal scale, Journal of Urban Affairs 25(2): 159-178. http://dx.doi.org/10.1111/1467-9906.t01-1-00004

Mills, A. 2006. Boundaries of the nation in the space of the urban: landscape and social memory in Istanbul, Cultural Geographies 13(3): 367-394. http://dx.doi.org/10.1191/1474474006eu364oa

Moncada, E. 2013. The politics of urban violence: challenges for development in the global south, Studies in Contemporary International Development 48(3): 217-239.

Özaydın, G. 2012. Taksim in üstü altına iniyor, Mimarlık Dergisi 364: 19-22.

Pinto, P. R. 2008. Urban social movements and the transition to democracy in Portugal, 1974-1976, The Historical Journal 51(4): 1025-1046. http://dx.doi.org/10.1017/S0018246X08007176

Resneck, J. Restrictions on social issues fueling demonstrations, USA Today, 3 June, 2013 [online], [cited 09 October 2013]. Available from Internet: http://www.usatoday.com/story/ news/world/2013/06/03/turkey-protest/2383461/

Taksim Meydanı Kentsel Tasarım Yarışması. 1987. Istanbul Municipality.

Taksim'e cami adı altında çarşı (no author), Milliyet, 12 August, 1994 [online], [cited 15 October 2013]. Available from Internet: http://gazetearsivi.milliyet.com.tr/Ara.aspx ?\&ilkTar=12.08.1994\&sonTar=12.08.1994\&ekYayin= \&drpSayfaNo=\&araKelime=cami\&gelismisKelimeA ynen $=\&$ gelismisKelimeHerhangi $=$ \&gelismisKelimeY akin $=$ \&gelismisKelimeHaric $=\&$ Siralama $=$ RANK\%20 DESC\&SayfaAdet $=20 \&$ isAdv $=$ true 
Taksim'de camiyi parka yapacağ $1 \mathrm{z}$ (no author), Milliyet, 9 January, 1995 [online], [cited 15 October 1013]. Available from Internet: http://gazetearsivi.milliyet.com.tr/Ara. aspx?\&ilkTar $=09.01 .1995 \&$ sonTar $=09.01 .1995 \&$ ekYayin $=\& \mathrm{drpSayfaNo}=\&$ araKelime $=$ erbakan $\&$ gelismisKelim eAynen=\&gelismisKelimeHerhangi $=\&$ gelismisKelime Yakin $=\&$ gelismisKelimeHaric $=\&$ Siralama $=$ RANK\%20 DESC\&SayfaAdet $=20 \&$ isAdv $=$ true

Uysal, Ü. E. 2012. An urban social movement challenging urban regeneration: the case of Sulukule, Istanbul, Cities 29(1): 12-22. http://dx.doi.org/10.1016/j.cities.2011.06.004

\section{MURAT GÜL}

Dr, Associate Professor, Department of Architecture, TOBB University of Economics and Technology, Söğütözü Caddesi No. 43, Ankara, Turkey.E-mail:mgul@etu.edu.tr

Murat Gül is an architectural and urban historian and the author of The Emergence of Modern Istanbul: Transformation and Modernisation of a City (London: 2009) and co-author of Istanbul Architecture (Boorowa: 2013).

\section{JOHN DEE}

Dr, Senior Lecturer, Architecture Program, International University of Sarajevo, Hrasnička cesta 15, 71210 Sarajevo, Bosnia and Herzegovina.E-mail: jdee@ius.edu.ba

John Dee is an urban planner with research interests in urban planning theory, urban history, heritage conservation and environmental impact assessment.

\section{CAHİDE NUR CÜNÜK}

PhD Candidate at Fatih Sultan Mehmet Vakuf University, Merkez Efendi Mah. Mevlevihane Cad., Yenikapı Mevlevihanesi No: 25, Zeytinburnu, Istanbul, Turkey.

E-mail: cahidenurcunuk@gmail.com

Research interests are in architectural and urban history, urban sociology. 